\title{
Syllinae (Polychaeta: Syllidae) from Australia. Part 1. Genera Branchiosyllis, Eurysyllis, Karroonsyllis, Parasphaerosyllis, Plakosyllis, Rhopalosyllis, Tetrapalpia n.gen., and Xenosyllis
}

\author{
Guillermo SAn Martín*1, PAT Hutchings² And María Teresa Aguado ${ }^{1}$ \\ ${ }^{1}$ Departamento de Biología (Zoología), Laboratorio de Biología Marina e Invertebrados, \\ Facultad de Ciencias, Universidad Autónoma de Madrid, Canto Blanco, 28049 Madrid, Spain \\ guillermo.sanmartin@uam.es·maite.aguado@uam.es \\ ${ }^{2}$ Aquatic Zoology, Australian Museum, 6 College Street, Sydney NSW 2010, Australia \\ pat.hutchings@austmus.gov.au
}

\begin{abstract}
Large collections of Syllidae (Polychaeta) from around Australia, housed at the Australian Museum (Sydney), have been examined and identified. Australian material from the Hamburgische Zoologische Museum der Universität, Hamburg, Germany was also examined, as well as some specimens lodged in other museums. All known Australian species of the subfamily Syllinae (Syllidae) belonging to the genera Branchiosyllis Ehlers, 1887 (9 species); Eurysyllis Ehlers, 1864 (1 species); Karroonsyllis San Martín \& López, 2003 (1 species); Parasphaerosyllis Monro, 1937 (1 species); Plakosyllis HartmannSchröder, 1956 (1 species); Rhopalosyllis Augener, 1913 (1 species), Tetrapalpia n.gen. (1 species), and Xenosyllis Marion \& Bobretzky, 1875 (2 species), are described and figured. Some were examined using the Scanning Electron Microscope to illustrate characters and methods of reproduction in this subfamily. Since there are numerous genera and species of Syllinae, the results will be presented in a series of several papers treating different genera. Keys to genera of Australian Syllinae will be provided in the final paper. Keys to species level are provided for genera having more than one Australian representative. Six new species are described: Branchiosyllis baringabooreen, B. orbiniiformis, B. carmenroldanae, $B$. thylacine, Xenosyllis moloch, and X. scabroides. A new genus, Tetrapalpia is described for the species Opisthosyllis dorsoaciculata. The genus Xenosyllis is described for the first time from Australia, as well as Branchiosyllis oculata Ehlers, 1887, and B. maculata (Imajima, 1966). A discussion of the reproduction and systematics of the subfamily is given.
\end{abstract}

San Martín, Guillermo, Pat Hutchings \& María Teresa Aguado, 2008. Syllinae (Polychaeta: Syllidae) from Australia. Part 1. Genera Branchiosyllis, Eurysyllis, Karroonsyllis, Parasphaerosyllis, Plakosyllis, Rhopalosyllis, Tetrapalpia n.gen., and Xenosyllis. Records of the Australian Museum 60(2): 119-160.

This is the third monograph contributing to our study of the Australian Syllidae, based on the large collections housed in the Australian Museum from all around Australia, but primarily from Western Australia and New South Wales, and

\footnotetext{
* author for correspondence
}

revision of material collected and described by HartmannSchröder in her series of papers on Australian polychaetes (1979-1991). This paper also summarizes published material of San Martín (2002, 2005), San Martín \& López (2003), San 